\title{
Changes in Water Levels and Storage in the High Plains Aquifer, Predevelopment to 2009
}

-V.L.McGuire

The High Plains aquifer underlies 111.8 million acres $(175,000$ square miles) in parts of eight States-Colorado, Kansas, Nebraska, New Mexico, Oklahoma, South Dakota, Texas, and Wyoming. The area overlying the High Plains aquifer is one of the primary agricultural regions in the Nation. Water-level declines began in parts of the High Plains aquifer soon after the onset of substantial irrigation with groundwater from the aquifer (about 1950 and termed "predevelopment" in this fact sheet). By 1980, water levels in the High Plains aquifer in parts of Texas, Oklahoma, and southwestern Kansas had declined more than 100 feet (ft) (Luckey and others, 1981). In 1987, in response to declining water levels, Congress directed the U.S. Geological Survey (USGS), in collaboration with numerous Federal, State, and local water-resources entities, to assess and track water-level changes in the aquifer. This fact sheet summarizes changes in water levels and drainable water in storage in the High Plains aquifer from predevelopment to 2009. Drainable water in storage is the fraction of water in the aquifer that will drain by gravity and can be withdrawn by wells. The remaining water in the aquifer is held to the aquifer material by capillary forces and generally cannot be withdrawn by wells. Drainable water in storage is termed "water in storage" in this report. A companion USGS report presents more detailed and technical information about water-level and storage changes in the High Plains aquifer during this period (McGuire, 2011).

In parts of the area that overlie the High Plains aquifer, farmers and ranchers began using groundwater for irrigation extensively in the 1930s and 1940s. Estimated irrigated acreage in the area overlying the High Plains aquifer increased from 1940 to 1980 , then changed slightly from 1980 to 2005 (McGuire, 2011): 1949-2.1 million acres, $1980-13.7$ million acres, 1997-13.9 million acres, 2002 12.7 million acres, $2005-15.5$ million acres. In 2005, irrigated acres overlaid 14 percent of the aquifer area, not including the areas with little or no saturated thickness (fig. 1).

About every 5 years, groundwater withdrawals for irrigation and other uses are compiled from water-use data and reported by the USGS and agencies in each State. Groundwater withdrawals from the High Plains aquifer for irrigation increased from 4 to 19 million acre-feet from 1949 to 1974. Groundwater

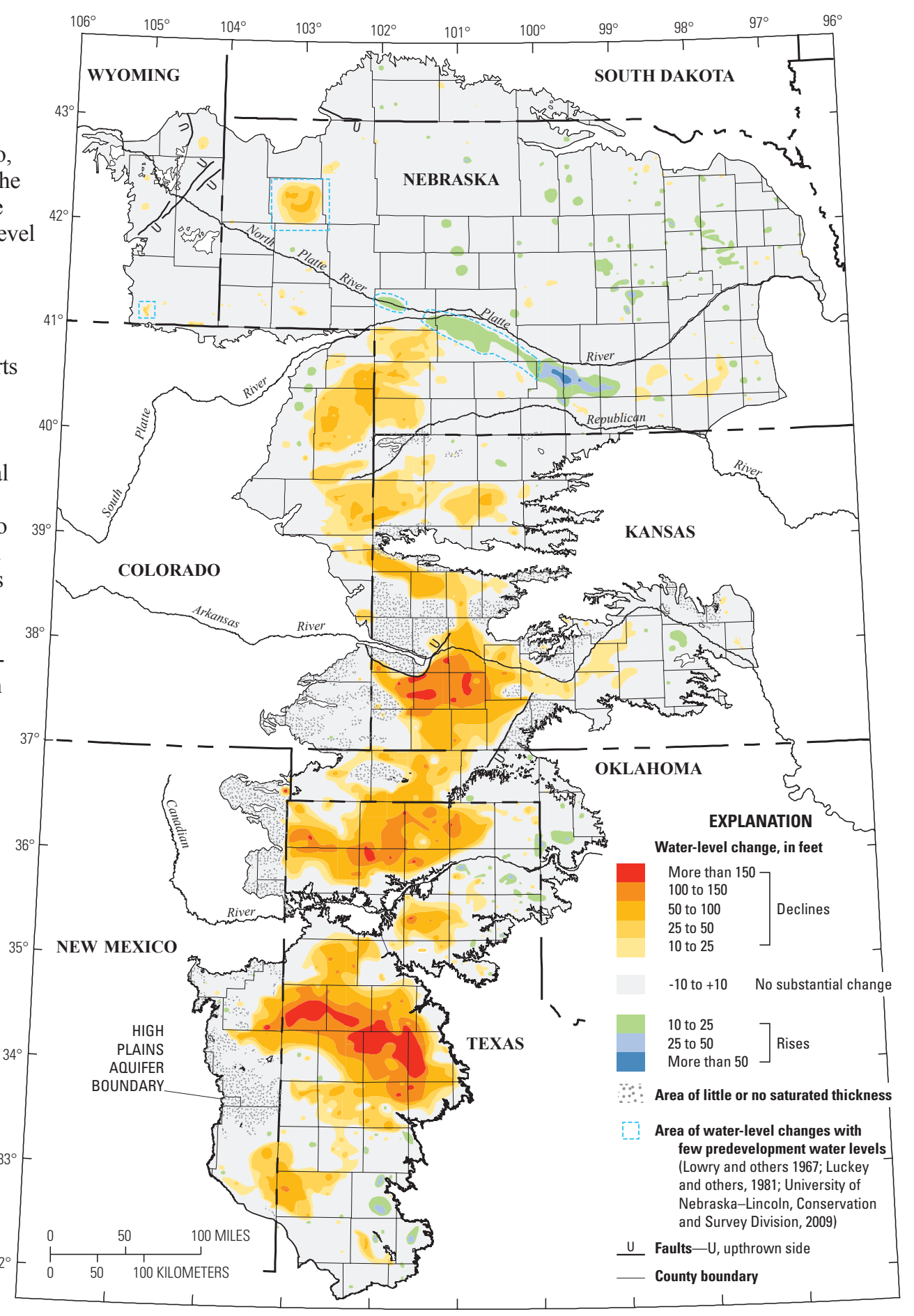

Base from U.S. Geological Survey digital data, 2001, 1:2,000,000 Albers Equal-Area projection

Standard parallels $29^{\circ} 30^{\prime}$ and $45^{\circ} 30^{\prime}$, central meridan $-101^{\circ}$

Figure 1. Water-level changes in the High Plains aquifer, predevelopment to 2009 (modified from Gutentag and others, 1984). 
withdrawals for irrigation in 1980, 1985, 1990, and 1995 were 4 to 18 percent less than withdrawals for irrigation in 1974. Groundwater withdrawals for irrigation were 21 million acre-feet in 2000 and 19 million acre-feet in 2005 (McGuire, 2011).

Long-term water-level changes in the aquifer result from an imbalance between discharge and recharge. Discharge primarily is groundwater withdrawals for irrigation, but also includes groundwater withdrawals for public supply and other uses.

Discharge also can include evapotranspiration where the water table is near the land surface, and seepage to streams, springs, and other surface-water bodies where the water table intersects the land surface. Recharge primarily is from precipitation. Other sources of recharge include seepage from streams, canals, and reservoirs, and irrigation return flows. Water-level declines may result in increased costs for groundwater withdrawals because of increased pumping lift and decreased well yields (Taylor and Alley, 2001). Water-level declines also can affect groundwater availability, surface-water flow, and near-stream (riparian) habitat areas (Alley and others, 1999).

\section{Water-Level and Storage Changes, Predevelopment to 2009}

The map of water-level changes in the High Plains aquifer from predevelopment (about 1950) to 2009 (fig. 1) was constructed using methods described by McGuire (2011). The map is based on water levels from 3,439 wells, which were measured in predevelopment and in 2009, and other previously published data in areas in Nebraska and Wyoming with few predevelopment water levels (Lowry and others, 1967; Luckey and others, 1981; University of Nebraska-Lincoln, Conservation and Survey Division, 2009). The water levels for 2009 were measured by numerous Federal, State, and local entities (See "Acknowledgments" section).

Ninety-nine percent of the water-level changes from predevelopment to 2009 ranged from a rise of $41 \mathrm{ft}$ to a decline of $178 \mathrm{ft}$. The area-weighted, average water-level change from predevelopment to 2009 was a decline of 14.0 feet. From predevelopment to 2009, water levels declined more than 10 feet in approximately 26 percent of the aquifer area, more than 25 feet in about 18 percent of the aquifer area, and more than 50 feet in about 11 percent of the aquifer area. In approximately 72 percent of the aquifer area, water-level changes ranged from a decline of 10 feet to a rise of 10 feet. In approximately 2 percent of the aquifer area, water levels rose more than 10 feet from predevelopment to 2009 (McGuire, 2011).

Water in storage in the High Plains aquifer in 2009 was about 2.9 billion acre-ft, which was a decline of about 273 million acre-ft (or about 9 percent) from predevelopment storage. Water in storage for predevelopment was estimated using both water in storage in 2000 and water-level changes from predevelopment to 2000 (McGuire, 2011).

\section{Acknowledgments}

The water-level data used in this report were provided by the following Federal, State, and local entities through data files or downloads from web sites and loaded into the U.S. Geological Survey National Water Information System (U.S. Geological Survey, 2011)_Colorado: Division of Water Resources (also known as the Office of the State Engineer); Kansas: Department of Agriculture-Division of Water Resources and Kansas Geological Survey (Kansas Geological Survey, 2010); Nebraska: Central Nebraska Public Power and Irrigation District, Natural Resources Districts, and University of Nebraska-Lincoln, Conservation and Survey Division; New Mexico: Office of the State Engineer; Oklahoma: Water Resources Board; South Dakota: Department of
Environment and Natural Resources; Texas: Groundwater Conservation Districts and the Water Development Board (Texas Water Development Board, 2010); Wyoming: State Engineer's Office; and Federal: Bureau of Reclamation, U.S. Fish and Wildlife Service, and U.S. Geological Survey offices in Colorado, Kansas, Nebraska, New Mexico, Oklahoma, South Dakota, Texas, and Wyoming. The author thanks the above entities for providing the water-level data and for their responsiveness regarding questions about the data.

\section{References Cited}

Alley, W.M., Reilly, T.E., and Franke, O.L., 1999, Sustainability of ground-water resources: U.S. Geological Survey Circular 1186, 79 p., available at http://pubs.usgs.gov/circ/circ1186/.

Gutentag, E.D., Heimes, F.J., Krothe, N.C., Luckey, R.R., and Weeks, J.B., 1984, Geohydrology of the High Plains aquifer in parts of Colorado, Kansas, Nebraska, New Mexico, Oklahoma, South Dakota, Texas, and Wyoming: U.S. Geological Survey Professional Paper 1400-B, 63 p., available at $h$ ttp://pubs.er.usgs.gov/publication/pp1400B.

Kansas Geological Survey, 2010, Wizard water well levels database: Kansas Geological Survey data, accessed September 2010, at http:// www.kgs.ku.edu/Magellan/WaterLevels/index.html.

Lowry, M.E., Crist, M.A., and Tilstra, J.R., 1967, Geology and groundwater resources of Laramie County, Wyoming, with a section on Chemical quality of ground water and of surface water by J.R. Tilstra: U.S. Geological Survey Water-Supply Paper 1834, 71 p., available at http://pubs.er.usgs.gov/publication/wsp1834.

Luckey, R.R., Gutentag, E.D., and Weeks, J.B., 1981, Water-level and saturated-thickness changes, predevelopment to 1980, in the High Plains aquifer in parts of Colorado, Kansas, Nebraska, New Mexico, Oklahoma, South Dakota, Texas, and Wyoming: U.S. Geological Survey Hydrologic Investigations Atlas HA-652, 2 sheets, scale 1:2,500,000, available at http://pubs.er.usgs.gov/publication/ha652.

McGuire, V.L., 2011, Water-level changes in the High Plains aquifer, predevelopment to 2009, 2007-08, and 2008-09 and changes in water in storage, predevelopment to 2009: U.S. Geological Survey Scientific Investigations Report 2011-5089, 13 p., available at http://pubs.usgs.gov/sir/2011/5089/.

Taylor, C.J., and Alley, W.M., 2001, Ground-water-level monitoring and the importance of long-term water-level data: U.S. Geological Survey Circular 1217, 68 p., available at http://pubs.usgs.gov/circ/circ1217/.

Texas Water Development Board, 2010, Groundwater database: Texas Water Development Board data, accessed December 2010, at http:// www.twdb.state.tx.us/GwRD/waterwell/well_info.asp.

U.S. Geological Survey, 2011, National Water Information System: U.S. Geological Survey data, available at http://waterdata.usgs.gov/ nwis/gw.

University of Nebraska-Lincoln, Conservation and Survey Division, 2009, Groundwater-level changes in Nebraska from predevelopment to spring 2009: University of Nebraska-Lincoln, Conservation and Survey Division map, accessed February 2011, at http://snr.unl.edu/ data/water/groundwatermaps.asp.

\section{For more information concerning this publication contact: \\ Director, USGS Nebraska Water Science Center, 5231 South 19th Street, Lincoln, Nebraska 68512, 402-328-4100 \\ Or visit the Nebraska Water Science Center Web site at: http://ne.water.usgs.gov}

This fact sheet is available at $h t t p: / / p u b s . u s g s . g o v / f_{S} / 2011 / 3069 /$ or from U.S. Geological Survey, Information Services, Box 25286, Denver Federal Center, Denver, CO 80225. 